\title{
Lactococcin 972: a homodimeric lactococcal bacteriocin whose primary target is not the plasma membrane
}

\author{
Beatriz Martínez, ${ }^{1}$ Juan E. Suárez ${ }^{2}$ and Ana Rodríguez ${ }^{1}$
}

Author for correspondence: Ana Rodriguez. Tel: +3485892131 .

1 Instituto de Productos Lácteos de Asturias, CSIC, Crta de Infiesto $s / n, 33300$ Villaviciosa, Asturias, Spain

2 Departamento de Biología Funcional, Área de Microbiología, Universidad de Oviedo, Oviedo, Asturias, Spain

\begin{abstract}
Lactococcus lactis subsp. lactis IPLA 972 was shown to produce a bacteriocin which had a bactericidal effect on sensitive lactococci. Production of lactococcin 972 reached a maximum during the late-exponential phase of growth. The bacteriocinogenic activity was heat-sensitive, active in the $\mathrm{pH}$ range 4.0-9.0 and showed low susceptibility to proteases. Purification of the bacteriocin rendered a single polypeptide of $7.5 \mathrm{kDa}$ (monomer) as shown by SDS-PAGE. Gels overlaid with a lawn of sensitive bacteria showed inhibitory activity at a point corresponding to $15 \mathrm{kDa}$. Changes in the electrophoretic conditions allowed the detection of a band at a position corresponding to that expected for a hypothetical dimer. Sequencing of the $\mathrm{NH}_{2}$-terminal end of lactococcin 972 revealed the sequence $\mathrm{NH}_{2}$-EGTWQHGYGV, which is not related to any other bacteriocin sequence present in the databases. Finally, lactococcin 972 did not induce the efflux of compounds previously incorporated into the cytoplasm of sensitive cultures nor did it inhibit macromolecular synthesis, suggesting that, in contrast to other bacteriocins, its primary target is not the plasma membrane.
\end{abstract}

Keywords: Lactococcus, bacteriocin, structure, mode of action

\section{INTRODUCTION}

Lactic acid bacteria are used extensively as starters in the manufacture of dairy products. They contribute simultaneously to the sensory attributes and to the preservation of fermented foods. Public concern about chemical food preservatives has attracted research interest in this last property, which is based on metabolites accumulating to inhibitory levels. These include organic acids, ethanol, hydrogen peroxide and bacteriocins (Piard \& Desmazeaud, 1991, 1992). In particular, bacteriocins (peptides or proteins that are bactericidal to sensitive strains) are believed to have great potential as natural food preservatives. Their production has been described in bacteria belonging to all main genera of the lactic acid bacteria group. Klaenhammer (1993) has placed the bacteriocins in four classes according to their chemical, structural and functional properties. The majority belong to classes I and II. Class I comprises the lantibiotics, small peptides that are post-translationally modified and thus contain unusual amino acids such as lanthionine. They have a wide spectrum of activity, nisin being the best known member of the group. Nisin is a lactococcal bacteriocin which has been licensed to be used as a food preservative (Food and Drug Administration, 1988). Class
II is made up of small, heat-stabie peptides, active on membranes, with either narrow or wide spectra of activity. Some of them depend on the complementary action of two different peptides (Nissen-Meyer et al., 1992; Allison et al., 1994). The third class includes large proteins and the fourth, peptides that depend on non-protein moieties to undertake their activities.

In this report, we describe a new bacteriocin that cannot be properly included in any of the classes described above since its active form seems to be a homodimer and its primary target is not the cytoplasmic membrane. This bacteriocin is produced by Lactococcus lactis subsp. lactis IPLA 972. This strain was identified in a previous screening for antagonistic properties among the wild lactococcal strains present in ripening home-made cheeses manufactured from raw milk in the absence of any starters in Asturias (northern Spain) (Martínez et al., 1995).

\section{METHODS}

Bacterial strains and culture conditions. Lactococous lactis subsp. lactis IPLA 972 is a wild strain isolated from a homemade cheese and was used as a lactococcin 972 producer (Martínez et al., 1995). L. lactis MG 1363, its derivative L. lactis

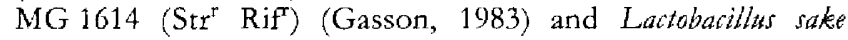


LMG 13558 were used as indicators. Cultures were grown in M17 broth (Biokar) supplemented with $0.5 \%$ lactose (IM17) for L. lactis IPLA 972 or with $0.5 \%$ glucose (GM17) for L. lactis MG 1363 and MG 1614. Lb. sake LMG 13558 was grown in MRS broth (Biokar). Solid media were prepared by adding $2.0 \%(\mathrm{w} / \mathrm{v})$ agar to the broths. All strains were incubated at $32^{\circ} \mathrm{C}$. When needed, streptomycin $\left(500 \mu \mathrm{g} \mathrm{ml}^{-1}\right)$ or tifampicin $\left(300 \mu \mathrm{g} \mathrm{ml}^{-1}\right)$ was used. Strains were stored at $-80^{\circ} \mathrm{C}$ in broth containing $10 \%(\mathrm{v} / \mathrm{v})$ glycerol and propagated twice before each experiment.

Bacteriocin detection and bioassay. Bacteriocin production was assayed by the agar diffusion test (Reddish, 1929). Plates were prepared by adding approximately $10^{5}$ sensitive cells of an overnight culture to molten M17 medium containing $1.2 \%$ (w/v) agar. After solidification, wells $(6.0 \mathrm{~mm}$ diameter) were made with a sterile cork borer and filled with $30 \mu \mathrm{l}$ of neutralized and filter-sterilized supernatants of L. lactis IPLA 972. After incubation, the diameter of the inhibition zone was measured. In order to quantify the bacteriocin activity, twofold serial dilutions of active supernatants were tested and the highest dilution that produced a clear zone of growth inhibition of the indicator lawn was defined as 1 arbitrary unit of activity $\mathrm{ml}^{-1}$ $\left(\mathrm{AU} \mathrm{ml} \mathrm{ml}^{-1}\right.$ ).

Preliminary characterization of lactococcin 972. Overnight supernatants of L. lactis IPLA 972 or purified bacteriocin preparations were subjected to heat treatments $(40,45,50,55,60$ and $100^{\circ} \mathrm{C}$ for $15 \mathrm{~min}$ ) and enzyme digestions using $\boldsymbol{\alpha}$ chymotrypsin, trypsin, proteinase $\mathrm{K}$, pronase $\mathrm{E}$ and $\alpha$-amylase, all at a final concentration of $1 \mathrm{mg} \mathrm{ml}^{-1}$ in $20 \mathrm{mM}$ Tris $/ \mathrm{HCl}$, $\mathrm{pH} 8.0$. The incubations were performed at $37^{\circ} \mathrm{C}$ for $1 \mathrm{~h}$. The remaining activity was measured as described before and untreated samples were used as controls. Aliquots of active supernatant were also adjusted to various $\mathrm{pH}$ values (2-12) with $\mathrm{NaOH}$ or $\mathrm{HCl}$, incubated at $21^{\circ} \mathrm{C}$ for $12 \mathrm{~h}$, and neutralized prior to testing the remaining activity. Finally, the supernatants were treated with catalase $\left(65 \mathrm{U} \mathrm{ml}^{-1}\right)$ to exclude inhibition by hydrogen peroxide.

Kinetics of lactococcin $\mathbf{9 7 2}$ production. LM17 broth was inoculated with overnight cultures of the producer strain $(1 \%$, $\mathrm{v} / \mathrm{v}$ ) and incubated at $32^{\circ} \mathrm{C}$ without agitation for $24 \mathrm{~h}$. Samples were removed at regulat intervals and analysed for growth (c.f.u. $\mathrm{ml}^{-\mathbf{1}}$ ), bacteriocin activity and $\mathrm{pH}$.

Purification and $\mathrm{NH}_{2}$-terminal amino acid sequence analysis. Active supernatants $(80 \mathrm{ml})$ obtained after centrifugation and neutralization of late-exponential-phase cultures of $L$. lactis IPL $A 972$ (fraction I) were precipitated with 5 vols acetone at $-20^{\circ} \mathrm{C}$ for $30 \mathrm{~min}$. After centrifugation at $4{ }^{\circ} \mathrm{C}$, the pellet was dried under vacuum and resuspended in $40 \mathrm{ml} 50 \mathrm{mM}$ sodium phosphate buffer, pH 7 (fraction II). Samples $(20 \mathrm{ml}$ ) were applied to a $5 \mathrm{ml}$ cation exchanger chromatographic column (High-S; Bio-Rad), previously equilibrated with $50 \mathrm{mM}$ sodium phosphate buffer, pH 7. The column was washed with $0.1 \mathrm{M} \mathrm{NaCl}$ in the same buffer and lactococcin 972 was eluted at $0.4 \mathrm{M} \mathrm{NaCl}$. The protein concentration was determined by the method of Bradford with the Bio-Rad Protein Assay kit. The purified bacteriocin preparation was stored at $-20^{\circ} \mathrm{C}$ without appreciable loss of activity.

To determine the $\mathrm{NH}_{2}$-terminal amino acid sequence of lactococcin 972, $10 \mu \mathrm{g}$ was spotted onto an Immobilon-P membrane (Millipore) and subjected to automated Edman degradation analysis (Edman \& Begg, 1967).

SDSPAGE and bioassay. Tricine/SDS-PAGE (Schägger \& von Jagow, 1987) was used to determine the molecular mass of lactococcin 972 with a $16.5 \% \mathrm{~T} / 3 \% \mathrm{C}$ separating gel and a $4 \%$ $\mathrm{T} / 3 \% \mathrm{C}$ stacking gel. After electrophoresis at $75 \mathrm{~V}$, the gels were cut in two pieces; one half was stained with Coomassie Brilliant Blue R-250 and the other half was washed and overlaid with an indicator lawn of L. lactis MG 1614 in streptomycin/ semisolid GM17 (0.7\% agar) (Bunhia et al., 1987).

Mode of action. Early-exponential-phase cultures $\left(\mathrm{OD}_{600} 0 \cdot 2\right)$ of L. lactis MG 1614 and Lb. sake LMG 13558 were harvested by centrifugation and resuspended in fresh medium containing purified lactococcin $972\left(6 \mu \mathrm{g} \mathrm{ml}^{-1}\right)$, or $50 \mathrm{mM}$ sodium phosphate buffer, $\mathrm{pH} 7$, as a negative control, and the incubation was continued. At different times, aliquots were removed to determine viable cell counts and the $\mathrm{OD}_{600}$ was measured in a spectrophotometer (Uvikon 930; Kontron Instruments).

To test the potential damage of the cell membrane, exponentiaily growing cultures of $L$. lactis MG 1363 were treated with rifampicin $\left(300 \mu \mathrm{g} \mathrm{ml}^{-1}\right)$ (at this concentration RNA synthesis is completcly inhibited) and $5 \mathrm{~min}$ later, $\left[5-{ }^{3} \mathrm{H}\right]$ uridine $\left(0.9 \mathrm{~Bq} \mathrm{mmol}{ }^{-1}, 37 \mathrm{kBq} \mathrm{ml}^{-1}\right)$ was added. Incubation proceeded for $20 \mathrm{~min}$ and was followed by addition of partially purified preparations of lactococcin 972 or nisin as a positive control. Samples were taken at different time intervals, filtered through nitrocellulose filters $(0.45 \mu \mathrm{m})$, extensively washed with warm GM17, and the radioactivity inside the cells was measured as described previously by González et al. (1994).

The possibie effect of lactococcin 972 on macromolecular synthesis was tested. The continuous incorporation of radiolabelled precursors into trichloroacetic-acid-insoluble material was measured in exponential cultures of L. lactis MG 1363 treated with a partially purified preparation of lactococcin 972. [metby $\left.l^{3} \mathrm{H}\right]^{\text {Thymidine }}\left(925 \mathrm{GBq} \mathrm{mmol}^{-1}, 37 \mathrm{MBq} \mathrm{ml}^{-1}\right)$, $\left[5^{3} \mathrm{H}\right.$ ] uridine $\left(0.9 \mathrm{~Bq} \mathrm{mmo}^{-1}, 37 \mathrm{MBq} \mathrm{mi}^{-1}\right)$ and a mixture of ${ }^{3} \mathrm{H}$-iabelled amino acids $\left(37 \mathrm{MBq} \mathrm{mi}^{-1}\right)$ were used at a final concentration of $37 \mathrm{kBq} \mathrm{ml}^{-1}$. For control purposes, lactococcin 972 preparations were replaced by the same volume of $2 \times \mathrm{M} 17$ broth. The samples were collected at different time intervals and processed as described by Rodríguez et al. (1986).

\section{RESULTS AND DISCUSSION}

\section{Production of lactococcin 972 and preliminary characterization}

The inhibitory activity produced by $L$. lactis subsp. lactis IPLA 972 was detected in cell-free supernatants of LM17 and GM17 cultures, indicating that its production was not

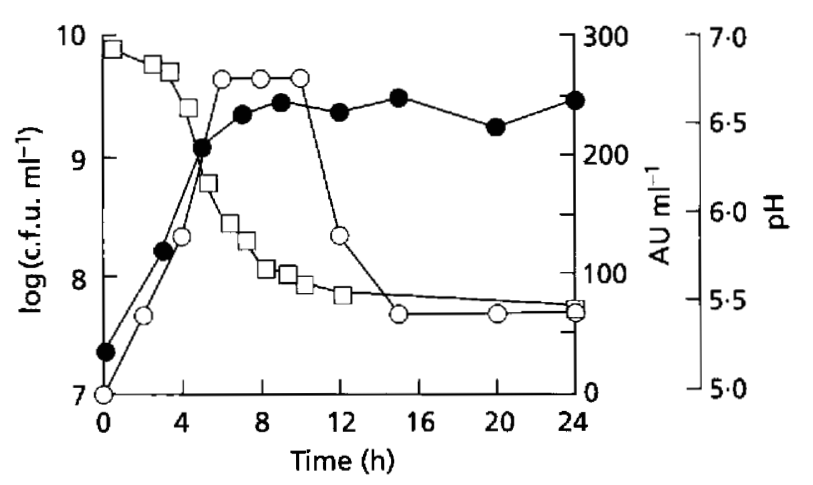

Fig. 1. Kinetics of production of lactococcin 972 in LM17 broth at $32{ }^{\circ} \mathrm{C}$ without agitation. At different time intervals samples were taken and c.f.u. $\mathrm{ml}^{-1}(\mathrm{O}), \mathrm{AU} \mathrm{ml} \mathrm{m}^{-1}(\mathrm{O})$ and $\mathrm{pH}(\square)$ were measured. L. lactis MG 1614 was used as an indicator. 
Table 1. Effect of different treatments on active supernatants of L. lactis IPLA 972

Relative activity was measured by an agar diffusion test against L. lactis MG 1614. - , No inhibition; + , slight inhibition; ++ , moderate inhibition; +++ , strong inhibition.

\begin{tabular}{|c|c|c|c|c|c|}
\hline $\begin{array}{l}\text { Enzymic } \\
\text { treatment }\end{array}$ & $\begin{array}{l}\text { Relative } \\
\text { activity }\end{array}$ & $\mathrm{pH}$ & $\begin{array}{l}\text { Relative } \\
\text { activity }\end{array}$ & $\begin{array}{c}\text { Heat } \\
\text { treatment } \\
(15 \mathrm{~min})\end{array}$ & $\begin{array}{c}\text { Relative } \\
\text { activity }\end{array}$ \\
\hline $\begin{array}{l}\text { Pronase E } \\
\text { Trypsin } \\
\text { Proteinase K } \\
\alpha \text {-Chymotrypsin } \\
\alpha \text {-Amylase } \\
\text { Catalase } \\
\text { Control }\end{array}$ & $\begin{array}{l}++ \\
+++ \\
+++ \\
+++ \\
+++ \\
+++ \\
+++\end{array}$ & $\begin{array}{r}4 \\
5 \\
6 \\
7 \\
8 \\
9 \\
10\end{array}$ & $\begin{array}{c}- \\
+++ \\
+++ \\
+++ \\
++ \\
+ \\
- \\
+++\end{array}$ & $\begin{array}{r}40^{\circ} \mathrm{C} \\
45^{\circ} \mathrm{C} \\
50^{\circ} \mathrm{C} \\
55^{\circ} \mathrm{C} \\
60^{\circ} \mathrm{C} \\
100^{\circ} \mathrm{C} \\
121^{\circ} \mathrm{C}\end{array}$ & $\begin{array}{c}++ \\
++ \\
+ \\
- \\
- \\
- \\
- \\
++\end{array}$ \\
\hline
\end{tabular}

Table 2. Purification of lactococcin 972

\begin{tabular}{|c|c|c|c|c|c|c|}
\hline Fraction & $\begin{array}{l}\text { Volume } \\
\text { (ml) }\end{array}$ & $\begin{array}{c}\text { Total } \\
\text { protein } \\
(\mu \mathrm{g})\end{array}$ & $\begin{array}{c}\text { Total } \\
\text { activity } \\
\text { (AU) }\end{array}$ & $\begin{array}{l}\text { Specific } \\
\text { activity } \\
\left(\mathrm{AU} \mu \mathrm{g}^{-1}\right)\end{array}$ & $\begin{array}{l}\text { Yield } \\
(\%)\end{array}$ & $\begin{array}{c}\text { Purification } \\
\text { (-fold) }\end{array}$ \\
\hline I. Supernatant & 80 & 16000 & 10640 & 0.665 & 100 & 1 \\
\hline II. Acetone precipitation & 40 & 9000 & 5320 & $0 \cdot 591$ & 50 & $0 \cdot 89$ \\
\hline III. Cation exchange & 16 & 200 & 2128 & $10 \cdot 640$ & 20 & 16 \\
\hline
\end{tabular}

repressed by glucose. The activity was first observed in the very-early-exponential phase and continued increasing until the late-exponential phase to a maximum activity of $266 \mathrm{AU} \mathrm{m}^{-1}$. Afterwards, the production apparently stopped but the amount of active bacteriocin in the supernatant remained constant. Once the culture entered into the stationary phase the activity abruptly decreased (Fig. 1).

To discover the chemical nature of the inhibitory compound produced by $L$. lactis IPLA 972, cell-free supernatants were subjected to different treatments. The results are summarized in Table 1 . The absence of inactivation by catalase suggested no involvement of hydrogen peroxide in the inhibition. Bacteriophages were excluded because serial twofold dilutions onto an indicator lawn did not form individual plaques and because the activity partially passed through filters with a cut-off limit of $10 \mathrm{kDa}$. Organic acids were also discarded because the inhibition was detected in neutralized supernatants. Furthermore, irreversible inactivation occurred at $\mathrm{pH}$ values $<4.0$ and $>9.0$. Lack of sensitivity to $\alpha$-amylase indicated that glucosidic moieties were not required for its biological activity. In contrast, although the activity was quite resistant to protease digestion it was partially inactivated by pronase $\mathrm{E}$. Since the peptidic nature of lactococcin 972 was proven after purification (see below), the reason for the resistance to proteases is still unsolved. However, it is important to note that this characteristic will be an advantage for its application in food systems where proteases are abundant. The activity was heatlabile, as indicated by its irreversible inactivation after treatment at $50^{\circ} \mathrm{C}$ for $15 \mathrm{~min}$. As far as we know, this is the first bacteriocin produced by a lactococcal strain which is heat-sensitive at neutral $\mathrm{pH}$ (Geis et al., 1983; Nettles \& Barefoot, 1993). In fact, this feature is restricted to large-complex bacteriocins produced by lactobacilli, such as helveticin J (Joerger \& Klaenhammer, 1986), acidophilucin A (Toba et al., 1991a) and the lacticins A and B (Toba et al., 1991b). However, the fact that lactococcin 972 passed through filters of known pore diameter indicated that it was between 3 and $10 \mathrm{kDa}$.

\section{Purification and $\mathrm{NH}_{2}$-terminal amino acid sequence}

Purification of lactococcin 972 was achieved through a two-step protocol comprising acetone precipitation and cation-exchange chromatography. The purification steps and recoveries are summarized in Table 2. Fig. 2 shows the chromatogram resulting from the last purification step. At $0.4 \mathrm{M} \mathrm{NaCl}$, the elution of a single peak of protein that coincides with the inhibitory activity can be observed. The purification procedure resulted in recovery of $20 \%$ of the initial activity.

Confirmation of the purity of the bacteriocin was obtained after $\mathrm{NH}_{2}$-terminal end sequencing, which rendered just one amino acid per cycle after the Edman degradation. The sequence obtained was $\mathrm{NH}_{2}-$ Glu-Gly-Thr-Trp-GlnHis-Gly-Tyr-Gly-Val-. No homology to lactococcal 


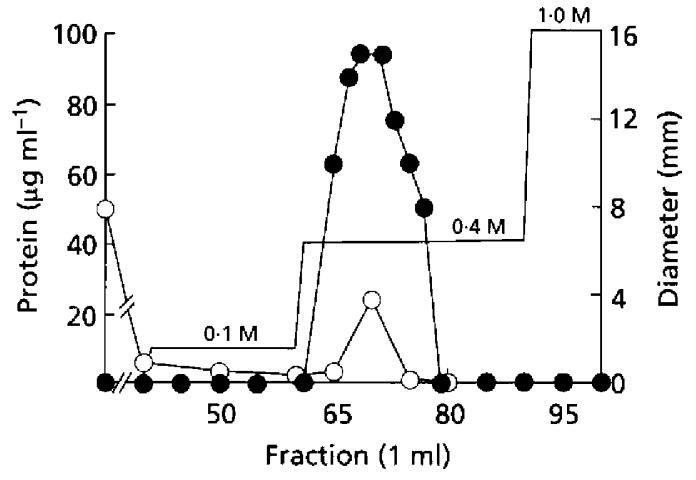

Fig. 2. Elution of lactococcin 972 at $0.4 \mathrm{M} \mathrm{NaCl}$ by cationexchange chromatography. The sample $(20 \mathrm{ml})$ was from acetone precipitation of the supernatant of a L. lactis IPLA 972 culture grown in LM17 broth. Fractions $(1 \mathrm{ml})$ were collected. Protein concentration (O) was determined by the Bradford assay and activity (O) was measured as the diameter of the inhibition halo on $L$. lactis MG 1614. $-\mathrm{NaCl}$ elution gradient.

bacteriocins or other proteins was found in the SWISSPROT database.

Bioautography of the culture supernatant (not shown) and of the solubilized acetone precipitate showed an inhibition zone at a level corresponding to a $15 \mathrm{kDa}$ polypeptide (Fig. 3b, lane 1). When a sample of pure bacteriocin was boiled and subjected to tricine/SDSPAGE, a single band of approximately $7.5 \mathrm{kDa}$ was observed (Fig. 3a, lane 2). As expected, this band did not show any inhibitory activity (Fig. 3b, lane 2). These data suggested that the active form of the bacteriocin was a homodimer that became denatured upon heat treatment of the samples prior to electrophoresis. To test this possibility, unheated samples were run and either stained
(Fig. 3a, lane 3) or subjected to bioassay (Fig. 3b, lane 3). In this first case, bands of 15 and $7.5 \mathrm{kDa}$ were observed and, as expected, only the upper band rendered the inhibitory activity.

This finding was further confirmed when it was observed that the sensitivity of lactococcin 972 to acid was also due to the dissociation of the two component peptides (the gels showing the bacteriocin after treatment at $\mathrm{pH} 2 \mathrm{had}$ the same appearance as those run after heating it). This seems to indicate that formation of the dimer is based on rather weak forces, perhaps of electrostatic or hydrophobic nature, although this question cannot be solved until the complete sequence of lactococcin 972 is available.

The dependence of the inhibitory activity on two peptides was first reported for lactococcin G (Nissen-Meyer et al., 1992) and later extended to other bacteriocins, such as lacticin $\mathrm{F}$ (Allison et al., 1994) and plantaricin S (JiménezDiaz et al., 1995) among others, although in all cases, the inhibition depended on the concerted action of two different peptides. In addition, these activities were heatresistant, indicating that strong, probably covalent, links existed between the two component peptides.

\section{Inhibitory spectrum of lactococcin 972 and mode of action}

Lactococcin 972 has a narrow spectrum of activity: it only inhibits other lactococcal strains and Lb. sake LMG 13558 (Martinez et al., 1995). Of 50 lactococcal strains isolated from natural dairy environments and from different bacterial coliections, all were found to be sensitive, including nisin $\mathrm{A}$ or nisin $\mathrm{Z}$ producers. In contrast, all the members of a set of other Gram-positive bacteria, which included Clostridium, Listeria, Enterococcus and Bacillus strains, were resistant. Most of the lactococcal bacteriocins have a narrow spectrum of activity, with the notable exception of the lantibiotics, such as nisin and lacticin 481 (a)

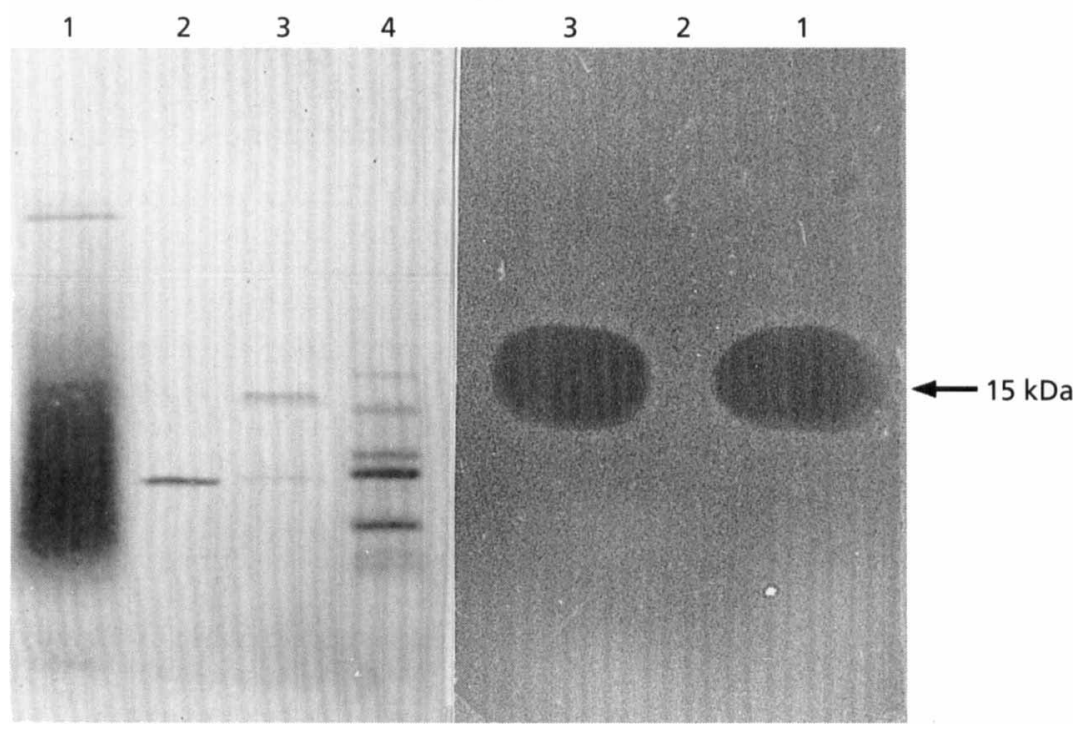

Fig. 3. Tricine/SDS-PAGE of lactococcin 972 and direct detection of its antimicrobial activity. L. lactis MG 1614 was used as indicator. (a) Gel stained with Coomassie Brilliant Blue R-250; (b) bioassay of inhibitory activity on a washed gel. Lanes: 1 , solubilized acetone precipitate of culture supernatant; 2, boiled purified lactococcin $972 ; 3$, unheated purified lactococcin $972 ; 4$, low-molecular-mass protein markers (16950, $14400,10600,8160,6210,3460$ and 2510 Da; Sigma). 

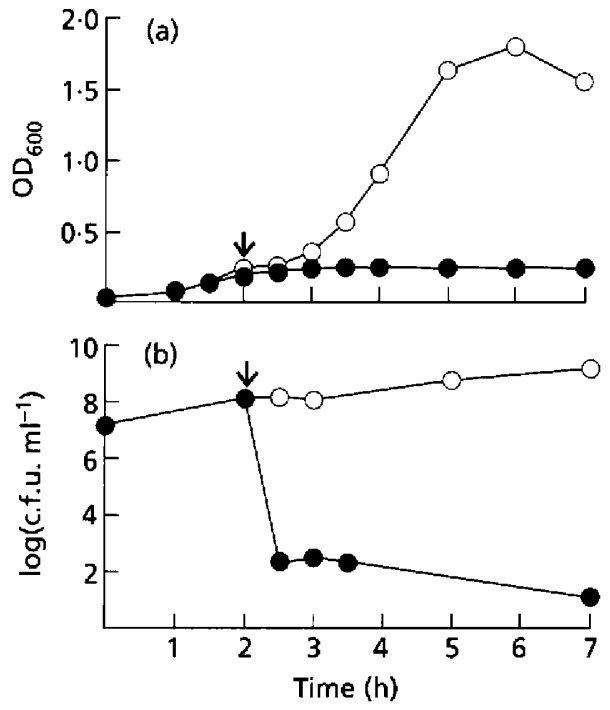

Fig. 4. Effect of purified lactococcin 972 on exponentially growing cells of $L$. lactis MG $1614 . O_{600}$ measurements (a) and viable counts $(b)$ of both treated $(O)$ and control $(O)$ cultures are shown. The arrow shows the addition of the bacteriocin (66 AU ml-1).

(Jack et al., 1995). Narrow-spectrum bacteriocins probably do not have a clear role as food preservatives; however, they can be used in, for example, accelerated maturation of cheese through promotion of the controlled lysis of sensitive lactococci present in the starter, which would allow direct interaction between the intracellular components and the fermenting substrate (Morgan $t$ t al., 1995).

The addition of lactococcin 972 to exponential cultures of L. lactis MG 1614 tesulted in an immediate arrest of the increase in optical density of the cultures (Fig. 4a), which was accompanied by a sharp decrease in the number of viable cells (Fig. 4b). These data indicate that lactococcin 972 is a bactericidal peptide that does not induce cell lysis as a secondary effect. Similar tesults were obtained when L. lactis MG 1363 and $L b$. sake LMG 13558 were tested.

All bacteriocins whose mode of action is known produce complexes that insert into the plasma membrane of sensitive bacteria, creating pores through which the cell material leaks (van Belkum et al., 1991; Nissen-Meyer $e t$ al., 1992; A bee et al., 1994). To test if this was also the case with lactococcin 972, two sets of experiments were devised. In the first of them, we analysed the effect of lactococcin 972 on cytoplasmic $\left[5-{ }^{3} \mathrm{H}\right.$ ] uridine, previously accumulated by $L$. lactis MG 1363 cells treated with rifampicin to inhibit the incorporation of the labelled precursor into RNA. No release of uridine was observed (Fig. 5d), whereas addition of nisin, a bacteriocin that forms membrane pores (Jack $e t a l ., 1995$ ), resulted in a fast and complete leakage of the intracellular uridine. This clearly suggests that lactococcin 972 does not create pores in the cytoplasmic membrane. The second experiment was carried out to analyse the effect of lactococcin 972 on
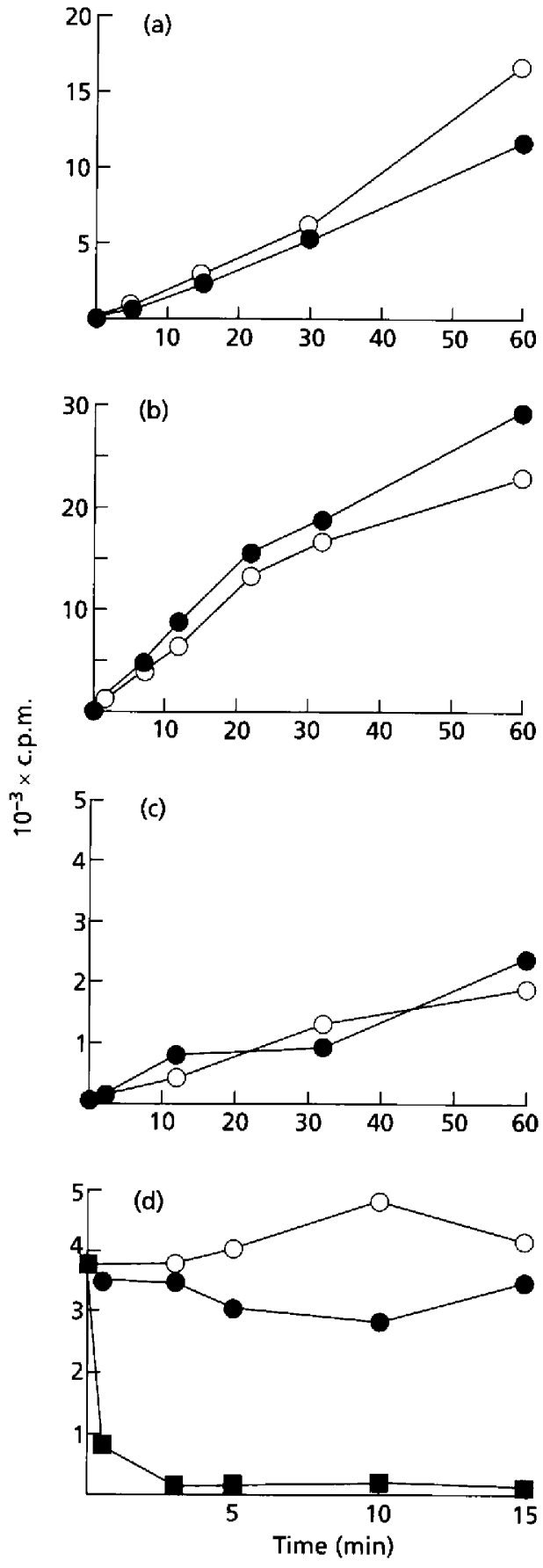

Fig. 5. Macromolecular synthesis in cultures of L. lactis MG 1363 treated $(\mathbf{O})$ or untreated $(O)$ with partially purified lactococcin $972\left(150 \mathrm{AU} \mathrm{ml} \mathrm{m}^{-1}\right.$ ) as measured by incorporation of exogenous labelled precursors into trichloroacetic-acid-insoluble material. (a) DNA; (b) RNA; (c) protein. (d) Efflux of [5- $\left.{ }^{3} \mathrm{H}\right]$ uridine, previously accumulated inside rifampicin-treated cells, after addition (at time zero) of lactococcin 972 (o) or nisin (a) (200 AU ml-1) as a positive control; $O$, control cultures without bacteriocin. Samples were taken in duplicate. The data shown are the means of three independent experiments.

macromolecular synthesis in sensitive cells. No inhibition of the incorporation of precursors into DNA (Fig. 5a), RNA (Fig. 5b) or proteins (Fig. 5c) was observed, even 
after $1 \mathrm{~h}$ of addition of the bacteriocin. This result contrasts with those obtained with plantaricin C (Gonzalez et al., 1994). In that case, addition of the bacteriocin to sensitive cultures caused an immediate cessation of all macromolecular syrthesis and the effux of labelled precursors previously accumulated into the cell.

We can conclude that lactococcin 972 forms a new class of lactococcal bacteriocin with a narrow spectrum of activity and whose primary target is not the plasma membrane. It is suggested that this activity relies on an unstable homodimeric structure, easily destroyed by heat and low $\mathrm{pH}$. The strong bactericidal activity against lactococcal strains shown by the lactococcin 972 producer could be used to design a single-or mixed-strain statter in which it is combined with leuconostoc strains. These starters would compete efficiently in food fermentations and would protect themselves against any potential contamination by other lactococcal strains.

Finally, it has been suggested that wild lactic acid bacteria isolated from natural dairy environments, in which no commercial starters are used, would be a good source of new bacteriocins which might have novel properties: lactococcin 972 is one such example.

\section{ACKNOWLEDGEMENTS}

We thank Dr (.. I.. ()tin for the Nl $\mathrm{I}_{2}$-terminal sequencing of lactococcin 972 and Dr R. Jiménez-D Gaz for helpful advice on purification procedures. This work was supported by grants A.193-(1873-(02-(12 and BIOT-(:T91-(1263 from the Comision Interministerial de Ciencia y Tecnologia of Spain and the Bridge Programme from the fiuropean Community, respecrively. Beatriz. Martinez is the recipient of a predoctoral feliowship from the Ministerio de Iiducación y Cicncia of Spain.

\section{REFERENCES}

Abee, T., Klaenhammer, T. R. \& Letellier, L. (1994). Kinetics studies of the action of lacticin $F$, a bacteriocin produced by Lactobacillus jobnsonii that forms poration complexes in the cytoplasmic membrane. Appl Environ Microbiol 60, 1006-1013.

Allison, G. E., Fremaux, C. \& Klaenhammer, T. R. (1994). Expansion of bacteriocin activity and host range uporn complementation of two peptides encoded within the lactacin F operon. ] Bacteriol 176, 2235-2241.

van Belkum, M. J., Kok, J., Venema, G., Holo, H., Nes, I. F., Konings, W. N. \& Abee, T. (1991). The bacteriocin lactococcin A specifically increases the permeability of lactococcal cytoplasmic membranes in a voltage-independent, protein-mediated manner. $J$ Bacteriol 173, 7934-7941.

Bunhia, A. K., Johnson, M. C. \& Ray, B. (1987). Direct detection of an antimicrobial peptide of Pediscoctus acidiatio in sodium dodecyi sulfate polyacrylamide gel electrophoresis. I Ind Microbiol 2, 319-322.

Edman, P. \& Begg, G. (1967). A protein sequenator. Eur J Biochem $1,80-81$.

Food and Drug Administration (1988). Nisin preparation : affirmation of GRAS status as a direcr human food ingredient. Food and Drug Adninistration Federai Regulation 53, 11247.
Gasson, M. J. (1983). Plasmid complements of Streptococcus lactis NCDO 712 and other lacric streptococci after protoplast-induced curing. J Bacteriol 154, 1-9.

Geis, A., Singh, J. \& Teuber, M. (1983). Potential of lacric streptococci to produce bacteriocin. Appl Emiron Microbigl 45, 205-211.

González, B., Arca, P., Mayo, B. \& Suárez, J. E. (1994). Detection, purification, and partial characterization of plantaricin $C, a$ bacteriocin produced by Lactobatillu plantartm strain of dairy origin. Appl Enwiron Microbiol 60, 2158-2163.

Jack, R. W., Tagg, J. R. \& Ray, B. (1995). Bacteriocins of Grampositive bacteria. Microbiol Rev 59, 171-200.

Jiménez-Díaz, R., Ruíz-Barba, J. L., Cathcart, D. P.، Holo, H., Nes, I. F., Sletten, K. H. \& Warner, P. J. (1995). Purification and partial amino acid sequence of plantaricin $S$, a bacteriocin produced by Lactabacillas plantarum LPCO10, the activity of which depends on the complementary action of two peptides. Appl Eniron Microbiol $61,4459-4463$.

Joerger, M. C. \& Klaenhammer, T. R. (1986). Characcerization and purification of helveticin $J$ and evidence for a chromosomally determined bacteriocin produced by Lactobacillus belveticus 481 . J Bacteriol 167, 439-446.

Klaenhammer, T. R. (1993). Genetics of bactcriocins produccd by lactic acid bacteria. FEMS Microbiol Rev 12, 39-86.

Martínez, B., Suárez, J. E. \& Rodríguez, A. (1995). Antagonistic activities of wild lactococcal strains isolated from homemade cheeses. J Food Prot 58, 1118-1123.

Morgan, S., Ross, R. P. \& Hill, C. (1995). Bacteriolytic activity caused by the presence of a novel lactococcal plasmid encoding lactococcins $A, B$, and M. Appi Finirn Microbin 61, 29953001.

Nettles, C. G. \& Barefoot, S. F. (1993). Biochemical and generic characteristics of bacteriocins of food associated lactic acid bacteria. $J$ Food Prot 56, 338-356.

Nissen-Meyer, J., Holo, H., Håvarstein, L. S., Sletten, K. \& Nes, Y. F. (1992). A novel lactococcal bacteriocin whose activity depends on the complementary action of two peptides. I Bacteriol 174, $5686-5692$.

Piard, J. C. \& Desmazeaud, M. (1991). Inhibiring factors produced by lacric acid bacteria. 1. Oxygen metabolites and carabolism endproducts. Lait 71, 525-541.

Piard, J. C. \& Desmazeaud, M. (1992). Inhibiting factors produced by lactic acid bacteria. 2. Bacteriocins and other antibacterial substances. Lait 72, 113-142.

Reddish, G. F. (1929). Methods for testing antiseptics. J Lab Clin Med 14, 649-658.

Rodríguez, A., Caso, J. L., Hardisson, C. \& Suárez, J. E. (1986). Characteristics of the developmental cycle of actinophage $\phi$ C31. I Gen Microbiol 132, 1695-1701.

Schägger, H. \& von Jagow, G. (1987). Tricine-sodium dodecyl sulphate-polyacrylamide gel electrophoresis for the separation of proteins in the range from 1 to $100 \mathrm{kDa}$. Anal Biob hem 166, 368-379.

Toba, T., Yoshioka, E. \& Itoh, T. (1991a). Acidophilucin A, a new heat labile bacteriocin produced by Lactobacillus acidophilus $\mathrm{LAPT}$ 1060. Leti Appl Microbiol 12, 106-108.

Toba, T., Yoshioka, E. \& Itoh, T. (1991b). Lacticin, a bacteriocin produced by Lactobacillus delbrueckii subsp. laciss. Lett Appl Microbiol 12, 43-45.

Received 19 April 1996; accepted 10 May 1996. 